\title{
CONCEPTUAL STUDY \\ Charter School Authorization: A Gateway to Excellence and Equity
}

\author{
Karen Stansberry Beard, PhD and Omotayo Adeeko, MA \\ The Ohio State University
}

\begin{abstract}
The lack of quality education many charter schools offer disproportionately and adversely impacts communities of color. This article considered two models of charter school governance in use by California and Ohio. The first model posits that a fundamental tenet of charter schools is freedom from the burdensome bureaucracy traditional public schools bear. Based on the argument that deregulation enables charter schools to employ more innovative instructional and management practices, it assumes higher achievement scores
\end{abstract}

would follow. The second model proposes to address educational inequality by increasing accountability on charter school authorizers by increasing regulatory practices. These models example the variety of governance models extant. In addition, arguments supporting each model are presented. The authors conclude with a discussion that supports the position that while autonomy is essential to maintaining the original objectives of charter schools, states must hold authorizers accountable for student achievement.
Charter schools are independently-run schools that receive state and federal funding, and operate under contracts with authorizing entities known as authorizers, sponsors, or chartering agencies. These terms are used synonymously. Authorizers are organizations which:

Can start a new charter school, set expectations and oversee school performance, and decide which schools should continue to serve students or not. Depending on state law, authorizers can

\begin{tabular}{|l|l|}
\hline \multicolumn{1}{|c|}{ Authorizers in California } & \multicolumn{1}{c|}{ Authorizers in Ohio } \\
\hline - Traditional public school districts & - Traditional public school districts \\
- County School Boards & - Not-for-profit organizations \\
- California Department of & - Education Service Centers \\
Education & - Universities \\
& - Ohio Department of Education, \\
& Office of School Sponsorship \\
\hline
\end{tabular}

Table 1. Authorizing organizations permitted in California and Ohio. be school districts, education agencies, independent boards, universities, mayors and municipalities, and not-for-profits (About National Association of Charter School Authorizers, n.d.).

Given the critical role that charter school authorizers have in school choice reform, they should be central to the discussion of charter school performance and accountability. Unfortunately, charter school policy continues to present issues in governance (e.g. balancing autonomy with accountability) as authorizers are often excluded from the conversation. These governance issues are disturbing considering how they disproportionately impact students, parents, and communities of color who comprise nearly half of the nation's charter school enrollments. As education reform rhetoric continues to shift from school-level improvements to system-wide change (Daly \& Finnigan, 2016), the conversation must include how policymakers will provide responsible governance of charter schools and the entities that authorize them. To establish high-quality school options, policymakers must 
expand the parameters of responsibility (Allen \& Mintrom, 2010) and require more oversight for charter school authorization.

This article focuses on California and Ohio authorization policy. Although the five states with the largest population of charter school students by percentage are Arizona, Colorado, Michigan, Louisiana, and Florida (U.S. Department of Education, 2016), the authors chose Ohio and California were chosen to review in this analysis for two reasons: these states educate large student populations of color, and they employ two contrasting models of authorizer governance. The models are presented as examples of the differences that exist in authorizer oversight that parents should be aware of when choosing charter schools. These two models are presented for policymakers to consider, especially those from states with similar student populations.

Student enrollment data (2014-2015) from California reflected that African American students made up $6 \%$ of the total public school enrollment ${ }^{1}$. African American students represent 9\% of California's charter school enrollment. This was second only to the Latinx student population. Latinx students made up $54 \%$ of the total public school enrollment, and $49 \%$ of the charter school population (National Alliance for Public Charter Schools, 2015).

Ohio's student enrollment data (2014-2015) reflected that African American students made up $16 \%$ of public school total enrollment. However, this subgroup occupies $46 \%$ of charter school seats, making African Americans the largest subgroup in Ohio charter schools. Ohio's Latinx public school student enrollment is 5\%. Latinx students occupy $7 \%$ of charter school seats (Ohio Department of Education, 2017; National Alliance for Public Charter Schools, 2015).

The 2015-2016 data reflect that the African American student population percentage for
California charters decreased by $0.5 \%$, while the Latinx student percentage increased by $1.3 \%$. In Ohio the African American percentage decreased by $0.6 \%$, and the Latinx percentage increased by $0.3 \%$. This may suggest that more Latinx parents are increasingly choosing charter schools as a viable option for the education of their children.

According to the 2014-2015 data, African American and Latinx students combined represent half of all students served by charter schools in Ohio (52.5\%) and California (57.6\%). The 2015-2016 data reflected a slight decrease in Ohio (to 52.2\%) and a slight increase in California (to 58.4\%). stated:

The National Education Association (2017) policy
Charters have grown the most in school districts that were already struggling to meet students' needs due to longstanding, systemic and ingrained patterns of institutional neglect, racial and ethnic segregation, inequitable school funding, and disparities in staff, programs and services. The result has been the creation of separate, largely unaccountable, privately managed charter school systems in those districts that undermine support and funding of local public schools. Such separate and unequal education systems are disproportionately located in, and harm, students and communities of color by depriving both of the high quality public education system that should be their right. (National Education Association policy statement, 2017).

The resulting failure or success of charter schools presents either a detrimental or beneficial educational quality to these vulnerable and traditionally underserved student populations.

\begin{tabular}{|c|c|c|c|c|c|}
\hline State & Race & $\begin{array}{c}\mathbf{2 0 1 4 - 2 0 1 5} \\
\text { Public School }\end{array}$ & $\begin{array}{c}\text { 2014-2015 } \\
\text { Charter School }\end{array}$ & $\begin{array}{c}\text { 2015-2016 } \\
\text { Public School }\end{array}$ & $\begin{array}{c}\text { 2015-2016 } \\
\text { Charter School }\end{array}$ \\
\hline California & African American & $6 \%$ & $8.8 \%$ & $5.8 \%$ & $8.3 \%$ \\
\hline California & Latinx & $53.6 \%$ & $48.8 \%$ & $54 \%$ & $50.1 \%$ \\
\hline Ohio & African American & $16.4 \%$ & $45.7 \%$ & $16.5 \%$ & $45.1 \%$ \\
\hline Ohio & Latinx & $4.8 \%$ & $6.8 \%$ & $5.04 \%$ & $7.1 \%$ \\
\hline
\end{tabular}

Table 2. Enrollment percentage by race and school type for California and Ohio. 
Lipman (2011) argued that working class African American and Latinx communities are inordinately destabilized by poor schooling and resulting closure of failing schools. She believed, "the disinvestment in schools is integral to disinvestment in African American and Latino/a neighborhoods" (p. 52). In states with large populations of African American and Latinx students attending charter schools such as Ohio and California, charter school policy is African American and Latinx education policy. By analyzing the governance mechanisms of both states and putting forth recommendations for state departments of education, it is our hope that policymakers across the country realize the possibilities of implementing school choice policies and governance structures toward stabilizing and enriching communities of color.

Finnigan (2007) theorized that the charter school concept is based on a trade-off or exchange of greater autonomy for increased results-based accountability. In this trade-off, state departments of education give charter schools public funds and increased autonomy in exchange for student academic achievement. A study by the Center for Research on Education Outcomes (2014) found that Ohio charter school students had such poor academic achievement scores that it was the equivalent of completing 43 fewer days of learning in math and 14 fewer days of learning in reading when compared to similarly situated peers in traditional public schools. The same data source reflected that California students reflected a deficiency of 14 days of learning in math but reflected gains in reading equivalent to 14 additional days of learning. These variances in academic achievement place students of color attending charter schools in precarious situations.

Further complicating these issues and central to this argument is the poor performance of the authorizing entities that oversee charter schools. Ohio has a new and robust authorizer evaluation system; therefore, Ohio data were used to illustrate this point. On a recent round of authorizer evaluations (October 2016), 21 of Ohio's 65 authorizers received a rating of 'poor', putting them at risk for immediate shutdown. Thirty-nine authorizers were rated 'ineffective', including the authorizer housed within the Ohio Department of Education (ODE), while only five authorizers received a rating of 'effective'. Not one authorizer received the department's top rank of 'exemplary'. If we accept charter schools as a tradeoff or exchange as Finnigan suggested, whereby charter schools receive public funding in return for adequately educated students, the data reveal that the public is getting the short end of the deal.

\section{Literature Review}

Although the body of research on charter schools is extensive, the literature pertaining to charter school authorizers is limited (Anderson \& Finnigan, 2001; Hassel \& Vergari, 1999; Henry \& Dixson, 2016; Palmer \& Gau, 2005). This article seeks to add to the scant literature on charter school authorizers while informing parents and communities of color of the educational responsibility owed to their children. Palmer and Gau (2005) recognized the significance of leadership and the critical responsibility of authorizers in creating effective charter schools. Said another way, the success or failure of a charter is a function of the quality of its authorizer. They stated, "the role of authorizer...is pivotal to the overall success of the charter movement. Yet surprisingly little is really understood about authorizers. They have rarely been scrutinized closely or evaluated" (p. 352). The following section outlines other recurring themes the literature provides relevant to charter school authorizers.

\section{Authorizers as Gatekeepers of School Choice}

Authorizers are the first defense, or "gatekeeping mechanism" (Henry \& Dixson, 2016, p. 220) in keeping ineffective schools from opening (or staying open) and allowing excellent schools to thrive and replicate. Ruble and Harris (2014) described the application process as the first screening tool in building highquality schools, as authorizers use applications to "control entry" (p. 369) into the system and deem only those worthy to open schools. Bulkley (2001) defined the application, in part, as a "quality control mechanism" (p. 14) to assist authorizers in determining which applicants are most likely to be successful. Vergari (2001) concurred, writing that granting a charter to an applicant "is arguably the most important decision to be made by the charter school authorizer" (p. 134). The author further stated that when an authorizer permits a school to open, it signals to the public that the school is "likely to succeed" (p. 134). Vergari further concluded that failing charter schools are due, in part, to the poor judgment of authorizers.

\section{Authorizer Accountability Practices}

The importance of full-scale accountability measures for authorizers have been determined. Palmer (2007) understood that the creation of value-added accountability systems would allow researchers to make better determinations of the relationship between authorizer quality and charter school 
performance. Zimmer, Gill, Attridge, and Obenauf (2014) argued that policymakers should determine a method for how authorizers oversee and support their schools. Vergari (2001) recognized the paradoxical nature of charter school and authorizer regulation stating, "charter school authorizers are shaping the regulatory boundaries of a policy reform based on deregulation" (p. 138). Similarly, Palmer and Gau (2005) discovered through interviews that authorizers struggle to balance the flexibility required of charter schools with the top-down administrative burdens of maintaining accountability.

As a means of checks and balances, Bulkley (2001) theorized that one method to increase accountability is to remove the renewal authority from charter school authorizers and place that responsibility with an external party. Doing so would remove "political disincentives" (p. 16) for keeping poorly performing schools open. Authorizer hopping is when charter school operators move from one authorizer to another to avoid being shut down for poor performance. The scenario is usually a variation of the following:

An authorizer signals to a failing school their plans to revoke or not renew the school's charter contract; the school seeks out a new authorizer who agrees to keep the school open; and the failing school, which was identified for closure, avoids accountability and remains open...Authorizer hopping represents the breakdown of charter school accountability (Doyle, 2014, p. 1).

To be sure to mitigate political incentivization, the external party review should be blind, eliminating the possibility of authorizer hopping.

\section{The Relationship Between Authorizer Type and Student Achievement}

Several researchers questioned if authorizer type (i.e. a state board of education, non-profit, school board) could predict student achievement. Zimmer et al. (2014) found that students attending Ohio charter schools originally authorized by non-profit authorizers had, on average, lower gains in math and reading than their similarly situated peers attending charter schools authorized by other entities. Conversely, Gleason, Clark, Tuttle, and Dwoyer (2010) found "no statistically significant relationship between impacts on Year 2 reading or mathematics scores and type of authorizer" (p. 95). Notably, they also found that variations in achievement scores within authorizer type was high. This indicated the need for authorizers to share best practices between and within authorizer types. Carlson, Lavery, and Witte (2012) argued for more rigorous studies to measure the relationship between authorizing type and mean levels of achievement so that drawing conclusions might occur from causal evidence (rather than correlational).

\section{Authorizer Motivation}

Motivation to authorize matters. Cowen, Fleming, and Gofen (2008) argued that motivation has "important implications" (p. 128) in accounting for the differences in achievement between charter schools. Ruble and Harris (2014) discussed how authorizers balance the competing goals of student achievement and other factors in authorization. For many authorizers, parent satisfaction (or dissatisfaction) and local political processes distorted the decision-making process causing authorizers to make choices based on factors other than student achievement. Zimmer et al. (2014) stated, "these [authorizer] fees may encourage the authorization of charter schools but create little incentive to scrutinize charter applications or performance of schools" (p. 62). They recognized the source of authorizer funding (often a percentage of the schools' per-pupil funding) potentially creates perverse incentives to sponsor new schools.

\section{Authorizing Schools}

Charter school authorization falls under various entities, including non-profit organizations, school districts, universities, and educational service centers. The literature, however, focused on the performance and challenges faced by non-profit and district authorizers. The decision was made for this study to focus on non-profit and district authorizers as supported by the literature. In this section, both non-profit authorizer performance and the specific challenges of district-based authorizing are described.

\section{Non-profit authorizers.}

Only two states, Minnesota and Ohio, have active non-profit organizations authorizing schools (Carlson et al, 2012; Zimmer et al., 2014). While the practice is not common across the country, it is nevertheless addressed in several articles. Hassel, Ziebarth, and Steiner (2005) suggested that a non-profit's possible connection to a community, commitment to a vision, and "credibility and visibility" (p. 10) within a particular population may make it an ideal candidate to be an authorizer. As previously noted, Carlson et al. (2012) found that schools authorized by non-profits had more variances in student achievement than 
other schools, while Zimmer et al. (2014) found that schools authorized by nonprofits had, on average, lower achievement in math and reading. While this preliminary research is inconclusive, it points to the need to closely monitor authorizer type in relation to achievement.

\section{District authorizers.}

The question if districts should be given the power to authorize new schools was frequently addressed in the literature. Conflicting interests, lack of desire to open charter schools, political pressure, and overburdened systems were all cited as reasons why districts may not be a good fit as charter school authorizers. Ruble and Harris (2014) found that New Orleans district schools were less likely to authorize charter schools because they were "disinclined to create competition for themselves through charter schools over which they have less control" (p. 365). Palmer (2007) believed "the best authorizers are those that actually desire the responsibility" (p. 305), which suggests that only organizations with the desire to authorize should do so, as long as they are able to demonstrate their capacity and potential for effectiveness.

Vergari (2001) observed that it was unusual for school districts to eagerly authorize charter schools:

Administrators of the traditional public school system frequently view charter schools as a distraction for other reform initiatives and as an unreasonable burden on school district budgets and personnel. School districts may also place implicit or explicit conditions on charter approval that are unappealing to charter school applicants. Thus, charter school advocates favor permitting an entity other than the school district to authorize charter schools (p. 132).

Palmer and Gau (2005) reiterated Vergari's findings, stating, "local school boards, on the whole, do not make the best charter school authorizers. They are often hampered by the influence of charter-averse education interest groups and local politics" (p. 354). Additionally, the authors wrote, local boards often do not have the necessary infrastructure to support additional schools in their districts.

The NEA (2017) proposed two safeguards for district charter authorization. The first states that a school district should authorize a charter school only if the charter is necessary to meet the needs of students and will meet the needs in a manner that improves the local public school system. The second proposes public charter schools should only be authorized by the same entity that oversees all district schools, such as a locally elected school board or a community-based authorizer to maintain local democratic control (National Education Association, 2017).

As highlighted in the literature, research reveals the challenges authorizers face. Many of the issues revolve around regulation, governance, and student achievement of the schools under their purview. The literature examined the difficulty in drawing causal relationships in authorizer-charter school research (Carlson et al., 2012; Ruble \& Harris, 2014). The literature also advocated for alternative pathways to increase access to quality authorizing (Palmer, 2007). More recently, authors describe the benefits of diversity in authorizer type and the insufficient infrastructure available to authorizers in holding charter schools accountable for student achievement (Carlson et al., 2012; Palmer \& Gau, 2005, Ruble \& Harris, 2014).

\section{Two Models of Authorizer Governance}

The creation of charter schools and the agencies that oversee them initially began as a new form of accountability in public school education. Rather than impede these schools with the burdensome bureaucracy known in traditional school districts, charter schools were to be free to innovate. In exchange for public funds, these schools were to provide a high-quality education to the state's children. That was meant to be the extent of accountability; to show that students were learning to a satisfactory level and they would be granted autonomy in designing an education plan for students (Anderson \& Finnigan, 2001; Hassel \& Vergari, 1999). This "radically different approach to education" (DeMaria, Ramsey, \& Bodary, 2015, p. 3) was free of regulation in its very design. However, the variation in oversight and the uneven academic performance of students of color warrant authorizer policy reform.

Two contrasting models of authorizer bureaucratic oversight from the states of California and Ohio are offered for the purpose of exampling the variety that exists in and among authorizer governance. The first model advocates that decreased regulation, with strict accountability measures, best reflects the true aim of charter school policy as it frees authorizers from bureaucratic burden. The second model argues for increased regulation and oversight from the state department of education to hold authorizers accountable for managing effective charter schools. 


\section{Model I: Decrease Regulation, Increase Accountability}

Advocates for charter school deregulation argue that policymakers must increase autonomy for charter school authorizers to create space for innovative practices first promised with the conception of charter schools. They argue, schools would have the "potential to unleash creativity and innovation...the flexibility that deregulation provides can help districts and schools lift student outcomes" (DeMaria, Ramsey, \& Bodary, 2015, p. 4). Rewarding accountability with autonomy is not new in educational leadership. District officials often reward schools with less oversight when they demonstrate effective achievement gains, giving "schools autonomy based on where they are in their success story" (Beard, 2015, p. 21). The Thomas B. Fordham Foundation, one of only five authorizers to receive an effective rating in 2016 in Ohio, calls this "the accountability/autonomy promise" (Palmer, Terrell, Hassel, \& Svahn, 2006, p.3). In a policy guide for Ohio legislators, the Foundation stated:

Ohio's charter schools are subject to constraining and sometimes conflicting laws and regulations. As it moves to live up to the accountability side of the bargain, Ohio must act as well to ensure that charter schools have the freedom to be different in ways that benefit their students (Palmer et al., 2006, p. 16).

In exchange for this deregulation, proponents argue, authorizers use flexibility and experimentation within schools to design better ways of addressing the needs of the state's most challenging student populations. States can monitor academic growth by enacting "rigorous standards and strict accountability" (DeMaria et al., 2015, p. 22). Model I advocates argue that decreased regulation is critical (Finnigan, 2007) if charter schools wish to maintain a separate and distinct identity from their traditional public school counterparts.

\section{Model I highlighted.}

California serves as a current example of Model I governance. As the state with the largest charter school market in the nation, it also has the largest number of charter school authorizers. However, as highlighted in a recent policy report by NACSA (2016), there is no state law that requires California authorizers to be evaluated, nor are there required sanctions for those who do not meet state requirements for authorizing. While authorizers may close schools with low student performance scores, there are no laws in place for the required closing of poorly performing or failing authorizers. Additionally, California law does not require standards-based authorizer evaluation or stipulate authorizer sanctions in cases of poor school performance (NACSA, 2016). In sum, California serves a Model I example as authorizers receive little guidance from state law and are, for the most part, left alone in overseeing charter schools. In return, authorizers are expected to maintain a strong portfolio of charter schools that meet established student performance benchmarks.

\section{A brief history of charter schools in California.}

In 1992, California became the second state in the United States to enact charter school law. A conversation on school vouchers and school choice was emerging, described by a California lawmaker as a "full-blown effort to reconstitute public education in California" (Hart \& Burr, 1996). Early proponents of the charter law imagined charter schools in California to be a middle ground between the status quo of traditional districts and total decentralization of public education. Charters would retain local control while permitting families and communities a greater variety of educational opportunities for their students. The bill also ensured that schools and authorizers would still be held accountable for student learning. The drafters of the original charter bill wrote, "in exchange for their unprecedented freedom of action, charter schools clearly carry a responsibility to be accountable to the public" (Hart \& Burr, 1996, p. 40). Senate Bill 1448 was passed in 1992 , authorizing the creation of charter schools in California and firmly establishing charter schools as another option in public education. California's charter school population has increased steadily since the passing of its charter law (see Figure 1).

Authorizer governance was not introduced or detailed until 2003. Assembly Bill 1137, Reyes, outlined specific authorizer oversight duties, including annual school visits and compliance monitoring with state reporting requirements. The law reads as follows:

Each chartering authority, in addition to any other duties imposed by this part, shall do all of the following with respect to each charter school under its authority: (a) Identify at least one staff member as a contact person for the charter school; (b) Visit each charter school at least annually; (c) Ensure that each charter school under its authority complies with all reports required of charter schools by law; (d) Monitor the fiscal condition of each charter 
school under its authority; (e) Provide timely notification to the department if any of the following circumstances occur or will occur with regard to a charter school for which it is the chartering authority: (1) A renewal of the charter is granted or denied, (2) The charter is revoked, (3) The charter school will cease operation for any reason (California Chapter 892, Section 8, Section 47604.32).

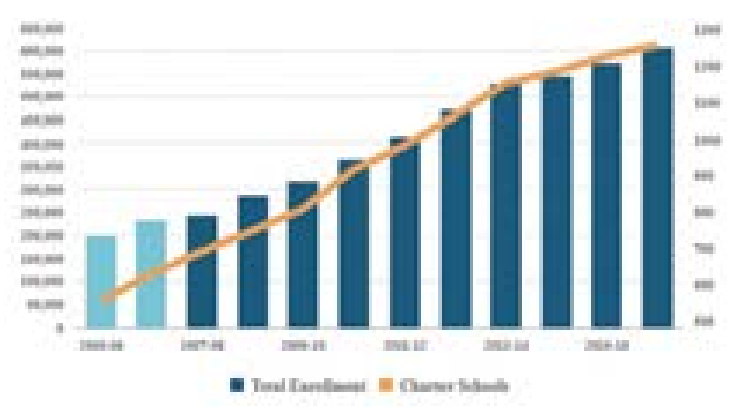

Figure 1. California charter school enrollment by year. Dark blue represents state reported data sources, light blue represents Common Core of Data source. National Alliance for Public Charter Schools. (2015). Public charter school's dashboard.

Retrieved from http://www.publiccharters.org/dashboard/home

Additionally, the bill required that a charter school meet at least one of several academic performance criteria as a prerequisite to receiving a charter renewal.

\section{Model II: Increase Regulation, Increase Accountability}

The second model of charter school governance differs from Model I in that it advocates for strong regulation and oversight of authorizing bodies. This model increases oversight using regulatory practices along with financial incentives and disincentives (Kane \& Staiger, 2002). Model II differs from Model I governance because it calls for more supervision of authorizers. It also differs from Model I in that it has built-in levers for sanctioning poorly performing authorizers. Additionally, Model II offers higher authorization caps giving them the right to authorize more schools. It also provides access to more funding which serves as rewards for authorizers who perform well.

\section{Model II highlighted.}

Ohio serves as a current example of Model II governance. Through strategic policymaking and increased regulatory statutes, the state has increased the efficiency of its authorizing sector. The changes made included requiring all authorizers to function under the management of the Ohio Department of Education (ODE), mandating that ODE provide annual feedback to authorizers, and requiring annual reports from ODE on authorizer performance. Pushing the weakest authorizers out of system decreased the number of authorizers in the state. The following section outlines the development of Ohio charter school authorizer policy to provide perspective on the accountability policy progression. While the policies have been developed, implementation remains inconsistent.

\section{A brief history of charter schools in Ohio.}

A 1997 response to a judicial ruling mandated that Ohio spend more money on education. As a result, the Ohio legislature enacted the state's first charter school law (Community School Legislative History, 2016). At the time Republican lawmakers believed that opening charter schools would serve as a cheaper, more effective option than opening more traditional public schools (Urycki, 2015). In 1999 legislators determined that 21 more urban school districts as well as districts determined to be in academic emergency could be permitted to open charter schools as an option for their students. Thus, from 1999 to 2007 Ohio's charter schools experienced a period of rampant growth (see Figure 2). The Ohio Department of Education, however, was unable to maintain regulation of new charters as it lacked the capacity to manage the increasing volume of charter schools in its portfolio. The lack of regulation and accountability in Ohio law created fertile ground for school choice advocates and educational entrepreneurs.

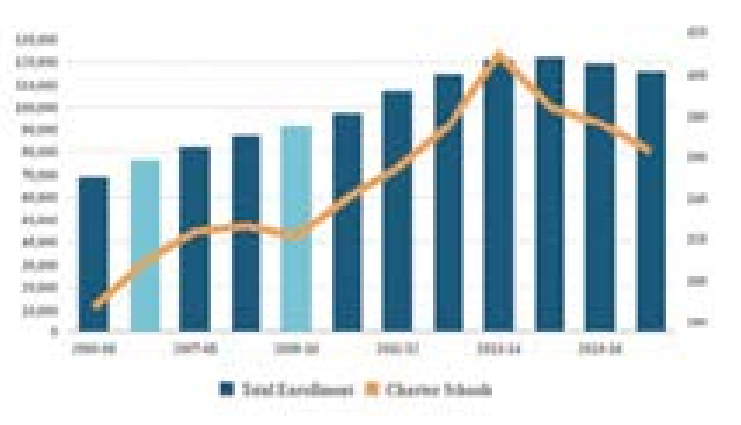

Figure 2. Ohio charter school enrollment by year. Dark blue represents state reported data sources, light blue represents Common Core of Data source. National Alliance for Public Charter Schools. (2015). Public charter school's dashboard.

Retrieved from http://www.publiccharters.org/dashboard/home 
The demand created from the increased number of charter schools prompted policymakers to change ODE's role to make it an authorizer of authorizers (Community School Legislative History, 2016). In this new capacity, ODE refocused its efforts to approve entities to become authorizers, provide technical assistance to authorizers, and monitor and evaluate the effectiveness of authorizer oversight (Ohio Revised Code 3314.015). House Bill 364 stated that ODE would only sponsor schools in critical need, shifting the burden of managing operations to authorizing agents outside of ODE.

House Bill 2 (The Ohio State Legislature, 2015) was passed in December 2015 and established a new structure for evaluating sponsors and holding them accountable for public funds. Up until this time, there was no legislation guiding outcome-based accountability for authorizers. The bill ushered in a wave of reforms in authorizer regulation: ODE was now required by law to annually rate all authorizers, incentives and consequences based on authorizer evaluations were detailed, authorizers were required to keep a record of financial responsibility, and finally, they were prohibited from selling additional goods or services to any school they authorized (Ohio Revised Code, 3314.46). This was designed as a deterrent for authorizers to keep failing schools open, as well as clarify the roles and responsibilities between authorizers and the schools in their portfolios.

Through analysis of recent policy changes in Ohio, it becomes clear why advocates for increasing regulation believe that Model II works better for charter school authorizers, operators, and their students. The National Association of Charter School Authorizers recommended that states with many types of authorizers "make it clear there is room only for quality authorizing and quality charter schools" (NACSA, n.d.) because the impact of charter schools on student achievement varies throughout schools (Gleason et al, 2010). Advocates of Model II support increasing regulation through strict and consistent use of high standards, performance management tools, public reports on performance, and evaluations with clear consequences based on student performance outcome measures.

Ohio, once referred to as the "wild, wild, West" of charter schools, has enacted policy measures designed to protect communities from reckless authorization practices. The new directions in authorization could better the current outcomes of Ohio students. These measures could increase the possibility of protecting students, families, and communities from the possible self-interests of charlatans posing as educational leaders. Recent findings by Ahn and McEachin (2017) show that while Ohio charter school students are closing some gaps in achievement, they are still less likely than their peers in traditional public schools to pass the state compulsory high school graduation test. House Bill 2 serves to professionalize charter school authorization and provide much-needed regulation and guidance for the gatekeepers of Ohio's charter sector.

\section{Concluding Discussion}

State departments of education, as well as other interested policy actors, must recognize and pursue their right to govern charter school authorizers. This pursuit should include identifying what works in effective governance, and using that knowledge to support student achievement. Accountability and autonomy are essential in maintaining the original objectives of the charter school movement: to liberate schools from bureaucratic oversight in order to allow for innovation. Advocates of high-quality education for all (including communities and parents) should recognize that increased regulations could ensure that authorizers and charter school operators equitably educate all children under their care.

Literature, data, and evidence suggest that for states seeking to increase high-quality educational opportunities, best practice would be to increase regulation and increase accountability for charter school authorizers. Attention to authorizer practice must shift to the forefront of school governance policy. With Lipman's (2011) understanding, it becomes apparent that closing charters results in community instability and impoverishment disproportionately impacting students of color. Raising performance levels and keeping effective schools open should increase stability for students of color and positively impact their communities. In addition to replicating best practices when appropriate, and reducing the number of authorizers, exemplary governance practices include promoting a diverse portfolio of schools authorized by one entity and informing parent choice. In the following section, both are briefly discussed.

\section{Promote diverse school portfolio systems}

The Center for Reinventing Public Education determined the portfolio strategy of school governance is a "citywide system of high-quality, diverse, autonomous public schools" ("Center for Reinventing Public Education," n.d.). The use of portfolios in cities such as Oakland, Los Angeles, and Cleveland, expands educational opportunities through school choice, performance-based 
accountability, and pupil-based funding. While no claim is made here that the portfolio strategy in and of itself guarantees academic gains, what is known is that the portfolio strategy has yielded some academic gains in Cleveland charter schools.

A 2014 Center for Research on Education Outcomes (CREDO) report noted, "Cleveland charter schools have significantly larger learning gains in both reading and mathematics. At the school level, 33\% of the charter schools have significantly more positive learning gains than their TPS [traditional public schools] counterparts in reading and math" (p. 8). If the portfolio strategy continues to yield gains such as Cleveland's, it has the potential to stand as a model of best practice in governing schools of choice serving students of color. The Cleveland Metropolitan School District authorizes or otherwise partners with almost twenty charter schools within its portfolio (Cleveland Metropolitan School District, n.d.). Authorization by school boards, as recommended by the NEA, allows local communities to invest in and support charter school operators as they work together to offer communities choice in schooling options.

\section{Informing parent choice}

Parents who choose to place their children in charter schools must be well informed with accurate data including measures of: student demographics, disaggregated achievement data, outcomes aligned to career and college readiness, graduation rates, SAT scores, college acceptance rates, and attendance at the very least. Otherwise, parents are playing Russian roulette while trusting authorizers to behave with the best interest of their children in mind. Sadly, many authorizers have become independently wealthy serving their own interests at the expense of a quality education for children. In the best interest of children, parents need to have accurate data available when considering charter options. At the very least, parents should know who the school authorizers are and their rating, if the state rates them. They should also have access to review the authorizer's history pertaining to their support for students of color including disaggregated academic outcomes.

Given the uneven results charters yield in educational performance outcomes, it is imperative to hold authorizers accountable for informing parents and the public about academic performance as required for other public educators. Providing accurate and current information gives parents and caregivers the ability to make informed decisions about the best educational opportunities for their children. Doing so empowers communities of color to partner with authorizers who have evidenced success in educating students of color, ensuring high-quality educational opportunities.

Whether policy actors are for or against charter schools is becoming increasingly inconsequential. Parents, many of whom are parents of children of color, are not only given the choice of charter schools as an alternative to traditional public education, but they are choosing them. The responsibility educators and policymakers must shoulder is to protect students, particularly vulnerable populations of students. Needed is a requirement for charter school authorizers to disclose disaggregated achievement data in addition to college readiness, as earlier described. Policymakers must hold authorizers accountable for the well-being of the children they serve by establishing policies that secure equity and excellence, and ensure conscientious implementation of those policies. The responsibilities are particularly important for educating children of color, especially in communities routinely destabilized by substandard schooling.

Educational leaders are responsible for student well-being in loco parentis. "Literally, in loco parentis means 'in place of the parent'" (Sperry, Daniel, Huefner, \& Gee, 1998, p. 629). The most significant application of this concept is to the teacher-student or administrator-student relationship in $\mathrm{K}-12$ settings (Rumel, 2013). The doctrine comprises two major tenets: (a) to provide a safe environment for students and (b) to protect students from foreseeable harm to both their physical and emotional well-being (Castaldo v. Stone, 192 F. Supp. 2d 1124, 1144 (D. Colo. 2001); Doe Parents No. 1 v. Dept. of Educ., 58 P.3d 545, 585, 2002). Foreseeable harm for poorly educated children of color is predicated by the fact they "experience disadvantages, inferior outcomes on almost every economically significant dimension including: earnings, education, housing, employment, status in the criminal justice system, and health" (Banaji \& Greenwald, 2013, pp. 314-315). Public school court cases have established precedents to safeguard students' interests. As a result, many of the policies guiding information disclosure provide data and information, thereby granting parents and communities the opportunity and ability to monitor patterns of activity and inactivity and to evidence outcomes of effectiveness.

Reimagining a vision for charter school regulation must now emerge in every state. Systemic change is complex. The layers of policy actors, from classroom teachers to state departments of education, both enrich and complicate the processes involved in implementing school choice policy. A tipping point 
in policy creation for charter school authorizers is approaching. It is imperative for states to hold charter schools accountable and implement policies requiring careful scrutiny of authorizer governance. Through improved regulation, accountability, rigorous authorizer evaluation, and increased transparency, states will then be able to ensure that students, families, and communities have high-quality school choices.

\section{Endnotes}

1. All percentages were rounded to the nearest whole number.

\section{ABOUT THE AUTHORS}

Karen Stansberry Beard, PhD is an Assistant Professor of Educational Administration and Educational Policy Affiliate at Ohio State University. Her research focuses on educational administration and preparing leadership to work successfully in diverse contexts.

Omotayo Adeeko is a graduate student in Educational Administration at Ohio State University. Her research interests include the policies and politics of school governance, school choice, and urban education.

Both authors contributed equally to the development of this manuscript sharing 50\% co-authorship.

Correspondence concerning this article should be addressed to:

Karen Beard or Omotayo Adeeko,

Department of Educational Studies, The Ohio State University,

Columbus, $\mathrm{OH} 43210$

beard.46@osu.edu or adeeko.5@osu.edu.

\section{REFERENCES}

About National Association of Charter School Authorizers. (n.d.). Retrieved from http://www. qualitycharters.org/about/.

Ahn, J., \& McEachin, A. (2017). Student enrollment patterns and achievement in Ohio's online charter schools. Educational Researcher, 46(1), 44-57.

Allen, A., \& Mintrom, M. (2010). Responsibility and school governance. Educational Policy, 24(3), 439-464.

Anderson, L., \& Finnigan, K. (2001, April). Charter school authorizers and charter school accountability. Paper presented at the annual meeting of the American Educational Research Association, Seattle, WA.

Assembly Bill of 2003, No. 1137, Chapter 892 Legislative counsel's digest (2003). Retrieved from http://leginfo.legislature.ca.gov/faces/ billTextClient.xhtml?bill_id=200320040AB1137.

Beard, K. S. (2015). Standing in the gap: Theory and practice impacting educational opportunity and achievement gaps. Urban Education, 1-29. 0042085915613553.

Banaji, M. R., \& Greenwald, A. G. (2013). Blindspot: Hidden biases of good people. New York, NY: Random House.

Bulkley, K. (2001). Educational performance and charter school authorizers: The accountability bind. Education Policy Analysis Archives, 9(37), $1-22$.

California Chapter 892, Section 8, Section 47604.32

Carlson, D., Lavery, L., \& Witte, J. (2012). Charter school authorizers and student achievement. Economics of Education Review, 31, 254-267.

Castaldo v. Stone, 192 F. Supp. 2d 1121 (D. Colo. 2001)

Center for Reinventing Public Education. (n.d.). Portfolio Strategy. Retrieved from http://www. crpe.org/research/portfolio-strategy

Center for Research on Education Outcomes at Stanford University. (2014). Charter school performance in Ohio. Palo Alto, CA. 
Cleveland Metropolitan School District. (n.d.). CMSD/Charter School Collaboration. Retrieved from http://www.clevelandmetroschools.org/ domain $/ 252$

Community School Legislative History. (2016). Ohio Department of Education. Retrieved from http:// education.ohio.gov/getattachment/Topics/ Community-Schools/Annual-Reports-on-OhioCommunity-Schools/Community-SchoolLegisHistory.pdf.aspx

Cowen, J., Fleming, D., \& Gofen, A. (2008). Measuring the motivation to charter: An examination of school sponsors in Texas. Journal of School Choice, 2(2), 128-154.

Daly, A., \& Finnigan, K. (2016). Thinking and Acting Systemically. Washington, DC: American Educational Research Association.

DeMaria, P., Ramsey, B. S., \& Bodary, S. R. (2015). Getting out of the way: Education flexibility to boost innovation and improvement in Ohio [Scholarly project]. Retrieved from https:// edexcellence.net/publications/getting-outof-the-way-education-flexibility-to-boostinnovation-and-improvement-in

Doe Parents No 1 v. Department of Education, 58 P.3d 545, 585 (Haw. 2002)

Doyle, D. (2014). Authorizer hopping: Motivations, causes and ways to stop it. Chicago, IL:

National Association of Charter School Authorizers. Retrieved from http://www.qualitycharters. org/wp-content/uploads/2015/08/PolicyBrief_ AuthorizerHopping.pdf

Finnigan, K. S. (2007). Charter school autonomy: the mismatch between theory and practice. Educational Policy, 21(3), 503-526.

Gleason, P., Clark, M., Tuttle, C. C., \& Dwoyer, E. (2010). The evaluation of charter school impacts: Final report. NCEE 2010-4029. National Center for Education Evaluation and Regional Assistance.

Hart, G., \& Burr, S. (1996). The story of California's charter school legislation. The Phi Delta Kappan, 78(1), 37-40.

Hassel, B. C., \& Vergari, S. (1999). Charter-granting agencies: the challenges of oversight in a deregulated system. Education and Urban Society, 31(4), 406-28.
Hassel, B. C., Ziebarth, T., \& Steiner, L. (2005). A state policymaker's guide to alternative authorizers of charter schools. Education Commission of the States.

Henry, K.L., \& Dixson, A.D. (2016). “Locking the door before we got the keys": Racial realities of the charter school authorization process in postKatrina New Orleans. Educational Policy, 30(1), 218-240.

Kane, T. J., \& Staiger, D. O. (2002). The promise and pitfalls of using imprecise school accountability measures. The Journal of Economic Perspectives, 16(4), 91-114.

Lipman, P. (2011). The new political economy of urban education: Neoliberalism, race, and the right to the city. New York, NY: Taylor \& Francis.

National Alliance for Public Charter Schools. (2015). Public charter school's dashboard. Retrieved from https://www.publiccharters.org/our-work/ research-and-data

National Association of Charter School Authorizers. (n.d.). State policy analysis: Scenario 2. Retrieved from http://www.qualitycharters.org/researchpolicies/archive/state-policy-analysis-scenario-2/

National Association of Charter School Authorizers. (2014). 2014 State policy analysis: Policy agenda. Washington, DC.

National Association of Charter School Authorizers. (2016). California 2016 state policy detail. Washington, DC.

National Education Association (2017). NEA Policy Statement on Charter Schools. Retrieved from https://ra.nea.org/nea-policy-statement-charterschools/

Office of Community Schools. (2016). Community schools FAQ. Retrieved from http://education. ohio.gov/Topics/Community-Schools/ FAQs-about-Licensure-for-Special-EducationTeacher\#FAQ188

Ohio Department of Education. (2017). Advanced reports. Retrieved from http://reportcard. education.ohio.gov/Pages/Power-User-Reports. aspx

Ohio Revised Code. § 3314.015 (2016), available at http://codes.ohio.gov/orc/3314.015 
Ohio Revised Code. § 3314.46 (2016), available at http://codes.ohio.gov/orc/3314.46

(The) Ohio State Legislature (2015). Retrieved from https://www.legislature.ohio.gov/ legislation/legislation-summary?id=GA131HB-2

Palmer, L. (2007). The potential of 'alternative' charter school authorizers. Phi Delta Kappan, 89(4), 304-309.

Palmer, L., \& Gau, R. (2005). Charter school authorizing: Policy implications from a national study. Phi Delta Kappan, 86(5), 352357.

Palmer, L., Terrell, M., Hassel, B., \& Svahn, C. P. (2006). Turning the Corner to Quality: Policy Guidelines for Strengthening Ohio's Charter Schools. The hThomas B. Fordham Institute,

The National Alliance for Public Charter Schools, and The National Association of Charter School Authorizers.

Ruble, W., \& Harris, D. (2014). To charter or not to charter: Developing a testable model of charter authorization and renewal decisions. Journal of School Choice, 8, 362-380.

Rumel, J. (2013), Back to the Future: The in loco parentis doctrine and its impact on whether K-12 schools and teachers owe a fiduciary duty to students. Indiana Law Review, Vol. 46, No. 3, 2013. http://dx.doi.org/10.2139/ ssrn. 2771309

Sperry, D. J., Daniel, P. T., Huefner, D. S., \& Gee, E. G. (1998). Education law and the public schools: a compendium. Norwood, MA: Christopher-Gordon Publishers.

United States Department of Education. (2016). Figure 3: Percentage of all public school students enrolled in public charter schools, by state: Fall 2014 [Map]. National Center for Education Statistics. Retrieved from https:// nces.ed.gov/programs/coe/indicator_cgb.asp

Urycki, M. (2015, May 7). Charter schools' history in Ohio. IdeaStream Ohio. Retrieved from http://wviz.ideastream.org/news/charterschools-history-ohio
Vergari, S. (2001). Charter school authorizers: Public agents for holding charter schools Accountable. Education and Urban Society, 33(2), 129-40.

Zimmer, R., Gill, B., Attridge, J., \& Obenauf, K. (2014). Charter school authorizers and student achievement. Education Finance and Policy, 9(1), 59-85. 